\title{
Against Spiritual Ecology: Reply to Sponsel's Comments
}

\author{
Andrew P. Vayda
}

Published online: 5 October 2014

(C) Springer Science+Business Media New York 2014

In replying to Leslie Sponsel's comments (2014b) on my review (Vayda 2014a), I must take the risk of further provoking him by repeating myself to some extent, as well as, at the end, saying something new and more positive. I refer to a risk here because a main response that Sponsel has been making to some of my criticisms has been not to answer them but rather to dismiss them because I have stated them previously, not only about his work but also the work of others. More about this shortly.

As far as the inaccuracy of my review is concerned, I concede that the reference in my review to Sponsel's discussion of pro-environment initiatives involving both science and spirituality failed to note that such initiatives mentioned by him are numerous and, in a few cases, detailed. However, I cannot accept this as an indication that anything else in my review is inaccurate or unreliable. Thus, to give only a few examples, I can confidently say that there is no inaccuracy in my stating, both in my review and in my listserv post (Vayda 2014b), that Sponsel and, as far as I know, his congeners have failed to respond to the challenge presented to spiritual ecology by cases in which spiritual or religious factors appear to be among those bringing about environmentally adverse outcomes, like the burning of an estimated 50 to 60 million trees per year in funeral pyres in India and the substantial amounts of carbon emissions resulting therefrom. Likewise, there is no inaccuracy in my stating that some of the chapters in Sponsel's book (2012), ike the one on the Burning Man festivals of the Nevada desert (chap. 17), have no clear relevance to an exposition of spiritual ecology or to the outline of its "intellectual history" which Sponsel (2012: xix) claims to be giving.

\footnotetext{
A. P. Vayda $(\bowtie)$

Distinguished Professor Emeritus, Rutgers,

The State University of New Jersey,

New Brunswick, NJ, USA

e-mail: apvayda@gmail.com
}

Nor is there anything inaccurate in my critical references to the high-sounding but unedifying statements that Sponsel approvingly cites or accepts from philosopher Roger Gottlieb and historian Donald Worster. With respect to the latter's statement which my review characterized as a pie-in-the-sky counterfactual, I must now go further on the basis of studies previously unfamiliar to me and question even Worster's premise that reverence for nature necessarily makes for better environmental stewardship. Thus, contrary to the premise, an article by Drew (2012) shows that complexities related, inter alia, to "multiple circulating epistemologies...layered within regional policies and politics" have the result that religious reverence for the River Ganges keeps actions from being taken in parts of India to reverse the river's degradation (see also the similar points being made by 1998 and Alley 2000, cited by Drew, and, also relevant to questioning Worster's premise, the somewhat different points made decades ago by Yi-Fu Tuan [1968: 187-188 and 1970: 248] about practical reasons why people frequently and consequentially act in ways that diverge from their own widely shared pro-environmental attitudes or values, like the Chinese ones in past centuries about quiescence towards nature).

As for Sponsel's charging me with bias, I suspect he may have in mind that I have gone on record (Vayda 2009: $33 \mathrm{ff}$. and 2011: 387) as being opposed to spiritual ecology, along with political ecology and even some versions of cultural anthropology, insofar as they have been designated as fields or subfields not, as ideally they should be, on the basis of what is to be explained by them but rather on the basis of $a$ priori judgments, theories, or biases about the kind of explaining they must do. Regardless of whether or not it's seen as a bias by Sponsel and others, I stand by this opposition and justify it on the grounds that such carving out of fields or subfields is conducive to confirmation bias and its baleful consequences for research and explanation as discussed at some length in my publications cited above, as well as in Vayda and Walters 
2011: Introduction and chaps. 14 and 15. Confirmation bias will also be discussed briefly below in the context of my explaining why I am not impressed by Sponsel's boast that his book has "a total of more than three dozen examples" of successful spiritual ecology solutions to environmental problems.

The first of the reasons for my not being impressed is the fuzziness or looseness of Sponsel's notion of what constitutes a spiritual ecology solution. Thus, both in my original review (Vayda 2014a) and in my subsequent listserv post (Vayda 2014b) I questioned his citing of biologist Wangari Maathai's tree-planting movement in Kenya (Sponsel 2012: chap. 16) as an example of such a solution. I did this because Maathai herself is quoted as saying that she undertook the work in 1977 as a pragmatic response to poor rural women's needs for cleaner water, more adequate food, and enough fuel for cooking and heating and that only later did she see the work as an expression of spiritual values. But Sponsel does not want to give up on this case and now mentions that religion was part of Maathai's early education and childhood as if that sufficed to ensure that she was being spiritual all along. I remain unconvinced, but, for the sake of argument, let's say she was. That would hardly justify regarding the tree-planting movement a spiritual ecology solution if Maathai was also being pragmatic and who knows what else in initiating and carrying out the tree-planting. Judging by Sponsel's use of the Maathai case, we should not be surprised if among his more than three dozen cases there are others which, when examined closely, also reveal complex interactions of causes or motivations behind the actions taken and thus raise questions about their being designated as spiritual ecology solutions.

To elucidate the second reason why I'm not impressed by Sponsel's boast of over three dozen examples, I will assume, again for the sake of argument, that they all do qualify as genuinely spiritual ecology solutions, my criticisms in the preceding paragraph notwithstanding. Even so, Sponsel's presenting those examples as cases in support of his views must be regarded as problematic because of what else is not presented by him. Here is where I must say more about confirmation bias. Defined as seeking or interpreting evidence in ways partial to existing beliefs, expectations, or a hypothesis in hand (Nickerson 1998: 175), it has been identified as perhaps the one problematic aspect of human reasoning that deserves attention above all others (ibid.). Evidently, however, Sponsel does not regard it as deserving attention at all and feels that my charging him with it can be dismissed simply as reflecting a perennial preoccupation (Sponsel 2014b, his response above to my review) or even an obsession of mine (Sponsel 2014a, his 4/5/14 listserv post) insofar as the criticisms are the same as those I have made before about the works of others.

In light of this dismissal, it is small wonder that Sponsel should regard his spiritual ecology success stories as providing strong support for his views. But it is, in large part, because of the concerns of mine dismissed by him that I am little satisfied by his examples or by how many of them there are. Thus, although Sponsel (2012) notes in his prologue that spiritual ecology faces "some serious obstacles and limitations" (pp. xviii-xix) and although he mentions some illustrations of these later in his book (e.g., in his chapter on the Dalai Lama), the book remains markedly deficient in critical consideration of spiritual ecology motivations, attitudes, and actions that do not lead to success in dealing with environmental problems. Far from being an idiosyncratic concern of mine, the methodological failure here is of a type that has been noted frequently through the ages. Indeed it was well illustrated as far back as the early 17th century in Francis Bacon's dramatic, classic statement on confirmation bias:

The human understanding when it has once adopted an opinion (either as being the received opinion or as being agreeable to itself) draws all things else to support and agree with it. And though there be a greater number and weight of instances to be found on the other side, yet these it either neglects and despises, or else by some distinction sets aside and rejects; in order that by this great and pernicious predetermination the authority of its former conclusions may remain inviolate. And therefore it was a good answer that was made by one who when they showed him hanging in a temple a picture of those who had paid their vows as having escaped shipwreck, and would have him say whether he did not now acknowledge the power of the gods, - "Aye," asked he again, "but where are they painted that were drowned after their vows?" (Bacon 1620 [Book One, Aphorism 46], cited in Vayda 2009: 32).

Although it may be difficult to assess the frequency of spiritual ecology failures relative to successes, there certainly are failures and they surely need to be taken into account for assessing the potential of spiritual ecology for dealing with environmental problems. I myself have referred previously (Vayda 2009: 35; Vayda 2014a) to sacred groves that either do not conserve or else stop conserving biodiversity, and I have referred above to how reverence for the River Ganges is failing to reverse its degradation. I have no doubt that many other failures can be found if we are not biased against finding them.

However, to end on the promised, more positive note, I must now acknowledge that Sponsel's response to my review has made me ask myself whether I have been criticizing his book unfairly because of my not having been clear about the kind of book that it is. Thus, even if the book falls short as a scholarly contribution presenting well supported, logically argued, and methodologically sound analyses and explanations, it may still have value as a compendium of diverse 
material so presented as to promote a worthy cause. Helping to avert what Sponsel (2012: xiii) refers to as "global ecological catastrophe" is certainly such a cause. Accordingly, if actions in the name of that cause are inspired by his book and turn out to have clearly and preponderantly positive results, then, my criticisms notwithstanding, some credit will be due to Sponsel for the inspiration that his book provides.

\section{References}

Alley, K. (2000). Separate domains: Hinduism, politics, and environmental pollution. In Chappie, C. K., and Tucker, M. E. (eds.), Hinduism and Ecology: The Intersection of Earth, Sky, and Water. Harvard University Press, Cambridge, pp. 355-388.

Bacon, F. (1620). Novum Organum. Excerpted in S. Hampshire (1958), The Age of Reason: The Seventeenth Century Philosophers, George Braziller, New York, pp. 23-30.

Drew, G. (2012). A retreating goddess? Conflicting perceptions of ecological change near the Gangotri-Gaumukh glacier. Journal for the Study of Religion, Nature, and Culture 6(3): 344-362.

Nagaraan, V. R. (1998). The earth as Goddess Bhu Devi: Towards a theory of embedded ecologies in folk Hinduism. In Nelson, L. E. (ed.), Purifying the Earthly Body of God: Religion and Ecology in Hindu India. State University of New York Press, Albany, pp. 269-296.
Nickerson, R. S. (1998). Confirmation bias: A ubiquitous phenomenon in many guises. Review of General Psychology 2(2): 175-220.

Sponsel, L. E. (2012). Spiritual Ecology: A Quiet Revolution. Praeger, Santa Barbara.

Sponsel, L.E. (2014a). Re: Vayda review of Sponsel's Spiritual Ecology. EANTH-L (Ecol/Env Anthropology listserv) Archive (https:// listserv.uga.edu/archives/eanth-1.html), Item \#029664, April 5, 2014

Sponsel, L.E. (2014b). Response to Vayda's review. Human Ecology. doi: 10.1007/s10745-014-9699-8.

Tuan, Y.-F. (1968). Discrepancies between environmental attitude and behaviour: Examples from Europe and China. Canadian Geographer 12: $176-191$.

Tuan, Y.-F. (1970). Our treatment of the environment in ideal and actuality. American Scientist 58: 246-249.

Vayda, A. P. (2009). Explaining Human Actions and Environmental Changes. AltaMira Press, Lanham.

Vayda, A. P. (2011). "Author Response", published together with five reviews of Vayda 2009. Dialogues in Human Geography 1(3): 370389.

Vayda, A. P. (2014a). Review: Leslie E. Sponsel, Spiritual Ecology, A Quiet Revolution. Human Ecology 42: 347-348.

Vayda, A. P. (2014b). Re: Vayda smear of Sponsel. EANTH-L (Ecol/Env Anthropology listserv) Archive (https://listserv.uga.edu/archives/ eanth-1.html), Item \#029696, April 7, 2014. [The title is from Brian McKenna's initial message in the string, Item \#029665 in the Archive.]

Vayda, A. P., and Walters, B. B. (eds.) (2011). Causal Explanation for Social Scientists: A Reader. AltaMira Press, Lanham. 